\title{
RECOVERY OF MAINTENANCE OBLIGATIONS \\ IN POLISH-AMERICAN RELATIONS \\ - END OF RECIPROCAL PRINCIPLE
}

\author{
Anna Juryk
}

\begin{abstract}
ABSTRAKT
This article concerns changes in recovery the child support and other forms of family maintenance in Polish-American relations after entered into force Convention of 23 November 2007 on the International Recovery of Child Support and Other Forms of Family Maintenance for the United States (1st January 2017). These changes primarily concern: cooperation between Polish and American Central Authorities, recognition and enforcement of foreign judgments, applications and required documents and legal assistance as well as costs. The 2007 Convention is a hope for maintenance creditors for more effective and faster enforcement of maintenance in the United States and the similarity to the provisions of the Regulation (EU) No 4/2009 gives a chance for unified global cooperation between States in recovery of maintenance, as well as constitutes facilitation for central authorities examining applications EU and non-EU States based on similar principles.
\end{abstract}

Key words: International Recovery of Child Support

* PhD, Assistant Professor, Department of Public Law, Institute of Law, Administration and Economics, Faculty of Political Science, Pedagogical University of Cracow, annajuryk@interia.pl. 


\section{INTRODUCTION}

The Convention of 23 November 2007 on the International Recovery of Child Support and Other Forms of Family Maintenance ${ }^{1}$ (hereinafter referred to as: "the Convention") entered into force for the United States on 1 January 2017. The Convention was prepared by the Hague Conference on Private International Law (hereinafter referred to as: "HCCH"). Poland and other EU Member States, except for Denmark, are bound by the Convention since 1 August 2014 by virtue of its approval by the European Union ${ }^{2}$. A Regional Economic Integration Organisation may accede to the Convention (Section 59 of the Convention). In such event the relevant Member States of the Organisation are also bound by this Convention.

The Convention shall ensure the effective international recovery of child support and other forms of family maintenance (Article 1). Furthermore; the Convention introduces not only the mechanisms of cooperation between the authorities of the Contracting States, but also the recognition and enforcement of maintenance decisions. This Convention addresses issues around maintenance obligations arising from a parentchild relationship towards a person under the age of 21 years $^{3}$, and between spouses or former spouses (Article 2.1).

Long-standing practice of the recognition and enforcement of maintenance decisions on the principle of reciprocity in Polish-American relations came to an end at the time when the Convention entered into force. The principle of reciprocity in Polish-American relations was based on the Communication of 18 November 1987on establishing a rule of reciprocity between Poland and the United States in the exercise of judgments

${ }^{1}$ EU Journal of Laws L 2011, No L 192, p. 39, hereinafter referred to as: the Convention.

${ }^{2}$ Council Decision of 9 June 2011 on the approval, on behalf of the European Union, of the Hague Convention of 23 November 2007 on the International Recovery of Child Support and Other Forms of Family Maintenance, EU Journal of Laws L 2011, No L 192, p. 39.

${ }^{3}$ Neither Poland nor the United States reduced the age limit to 18, even though they were entitled to make such reservation, based on the Article 2.2 of the Convention. 
including the maintenance decisions arising from the family relationships ${ }^{4}$ and the declaration of all states of the United States on recognition of Polish maintenance decisions based on the principle of reciprocity. Even though, the Communication of 18 November 1987 did not include such situation, the principle of reciprocity was also utilized to issue a decision granting maintenance ${ }^{5}$.

The principle of reciprocity was also a basis for recognition and enforcement of maintenance decisions also in relations between the United States and Australia, Canada (provinces of British Columbia, Monitoba and New Scotland), the Czech Republic, Slovakia, Ireland, Portuguese, The Great Britain and Germany ${ }^{6}$. The foreign decisions of other states were recognized and enforced by the state courts of the United States based on the similarities of the foreign provisions and the provisions of UIFSA on effectiveness of foreign judgments.

Recovery of maintenance in Polish-American relations was not effective. As a reason for a low effectiveness can be named: the lack of provisions describing the responsibilities of the authorities to transmit application for the establishment of maintenance abroad, or the lack of provisions enforcing obligations on the United States authorities to answer to such question within defined period of time or taking appropriate steps to enforce maintenance $a_{b r o a d} 7$. Due to these reasons many requests sent to the United States authorities went unheeded or in extreme cases responses were sent few years later. The Convention shall prevent a similar situation. The Convention warrants that the requests will be considered within reasonable time by introducing the timeframes and using the electronic communication.

${ }^{4}$ Polish Journal of Minister of Justice 1987, No 4, 42, Declaration - Poland Reciprocity. In Family Support [Maintenance) Enforcement, October 16, 2017 www.acf.hhs.gov/ programs/cse/international/index.html.

${ }^{5}$ J. Ignaczewski. M. Karcz, W. Maciejko, M. Romańska, Alimenty: komentarz, ed. J. Ignaczewski, wyd. 4, Warszawa: C.H. Beck: 2016, 522; J.M. Łukasiewicz, M. Aksamitowska-Kobos, „Egzekucja alimentów na rzecz dziecka od zobowiązanego przebywającego na terenie USA na przykładzie stanu Illinois oraz New York" [Enforcement of child support payments from a US resident on the example of Illinois and New York], Monitor Prawniczy (12) 2016:647.

6 October 21, 2017 https://www.acf.hhs.gov/sites/default/files/ocse/im_03_01a1.htm\#j.

${ }^{7}$ J.M. Łukasiewicz, M. Aksamitowska-Kobos, op. cit., 652-653. 


\section{RATIFICATION OF THE CONVENTION IN THE UNITED STATES}

The United States was the first State which signed the Convention on 23 November 2007; however, the ratification process lasted almost 9 years.

Because the Convention is not self-executing act ${ }^{8}$, it requires implementation to the federal and states laws' . The self-executing act are the international agreement which provisions are precise and detailed enough to have a direct impact, without the need of an implementation to national law ${ }^{10}$.

Such ratification method brings certain risk, for example: some provisions of the convention may not be implemented or might be implemented incorrectly. Another source of risk are different systems of law sources in Poland and in the United States. In Poland, the international agreement is part of the domestic legal order and applies direct after it is ratified and published in the Official Journal (Article 91.1 of the Polish Constitution). In the event of any conflicts between an Act and an international agreement ratified upon prior consent granted in the Act, the ratified international agreement will prevail over the Act (Article 91.1 of the Polish Constitution ${ }^{11}$ ).

A precedent, as a source of law, is playing an import an role in the American law. This causes that the United States legal system is not uniform. The United States Constitution dated 1787 is the most important source of law and all other legal acts have to be consistent with this fundamental statute. The United States Constitution defines the scope of federal legislation. The United States legal system is created by the federal and

${ }^{8}$ Medellin v. Texas, 552 U.S. 491, 128 S.Ct. 1346, 170 L.Ed.2d 190 (2008).

${ }_{9}^{9}$ E.M. Fish, "The Uniform Interstate Family Support Act (UIFSA) 2008: Enforcing International Obligations Through Cooperative Federalizm”, Journal of the American Academy of Matrimonial Lawyers (24) 2011: 34. October 23, 2017 http://aaml.org/sites/ default/files/MAT105_3.pdf

${ }^{10}$ The UN Convention on Contract for the International Sale of Goods made in Vienna of 11 April 1980 (is an example of a self-executed agreement (Polish Journal of Laws 1997, No 45, item 286). The Vienna Convention replace the Federal Commercial Code in the field covered by this Convention

${ }^{11}$ Constitution of the Republic of Poland dated 2 April 1997 (Polish Journal of Laws 1997, No 78, item 483). 
state laws. On the territory of one state are in force different laws, because the state authorities transferred many of their lawmaking competences to different territorial divisions (i.e. counties, districts) or on government agencies. The United States Constitution and the federal laws take precedence over the state laws and other laws applicable territorially.

The United States implemented the Convention by amending the federal act Uniform Interstate Family Support Act (UIFSA) dated $1992^{12}$ on recovery of maintenance between particular states. UIFSA applies only to recovery of child support and between spouses. UIFSA was adopted by all states only in 1996, because then the president signed an act according to which the receipt of federal funds for social aid for children was made conditional on acceptance of the UIFSA in particular state.

UIFSA consists of nine articles, each articles is divided in sub-section:

a) General provisions (Article 1),

b) Jurisdiction (Article 2),

c) Civil Provisions of General Application (Article 3),

d) Establishment of child support or determination of parentage if decisions issued in other states or countries may not be enforced under UIFSA (Article 4),

e) Enforcement of child support decision and the preceding registration procedure with an opportunity to question the validity of a decision awarding child support or refusal registration for enforcement (Articles 5 and 6),

f) Support proceeding under the Convention (Article 7),

g) Extradition an individual found in the state who is charged criminally in the other state with having failed to provide for the child support (Article 8),

h) Final provisions (Uniformity of application and construction, Transitional provision, Effective Date) (Article 9).

Article 7 of the UIFSA, which was essential to the implementation of the Convention, was added in 2008 as an outcome of amendments to

12 September 9, 2017 http://www.uniformlaws.org/shared/docs/interstate\%20family\%20support/UIFSA_2008_Final_Amended\%202015_Revised\%20Prefatory\%20Note\%20 and\%20Comments.pdf with changes 1996, 2001, 2008 r. UIFSA replaced Uniform Reciprocal Enforcement of Support Act of 1950 r. (URESA). 
UIFSA $^{13}$. Such change limited the impact of UIFSA on international issues regulated by the Convention, however such impact has not been excluded entirely. UIFSA applies to matters not regulated by the Convention and to countries which are not yet contracting parties to the Convention. In the event of conflict Article 7 of the UIFSA will prevail over Article 1.6 UIFSA (UIFSA, Article 1 section 105 and Article 7 section 702).

We should bear in mind that the Convention and UIFSA, because of the difference in the legal systems, not always use the same legal terms (e.i. obligee instead of creditor, obligor instead of debtor, registration of order in place of recognition and enforcement). It is extremely important to align the terminology used in the Convention to the terminology utilized in American law (UIFSA, Article 1 section 102 and Article 7 section 701).

The ratification process was made easier by the fact that experts of the Uniform Law Commission participated not only in a preparation of the amendment to the UIFSA dated 2008 implementing the Convention, but also in works on the text of the Convention ${ }^{14}$.

The ratification process involved few steps. On September 29, 2010 the United States Senate gave its advice and consent to ratification of the Convention. Senate passed the changes introduced to the federal legislation (UIFSA dated 2008), through the adoption of the Public Law 113183, which was signed by the President on 29 September 2014. This legislation requires all states to adopt UIFSA (2008) before the end of 2015. The next steps included the ratification of the Convention by the President and deposit the instrument of ratification to the Ministry of Foreign Affairs of the Netherlands (the Depositary of the Convention).

The Convention is in force in all states of the United States ${ }^{15}$. Article 61 in conjunction with Article 63 of the Convention gives a state, which has two or more territorial units in which different systems of law are

${ }^{13}$ The Proposal adapted on 30 September 2008 by National Conference of Unification of International Laws Commissioners.

${ }^{14}$ Uniform Interstate Family Support Act: 107, October 25, 2017 http://www.uniformlaws.org/shared/docs/interstate\%20family\%20support/UIFSA_2008_Final_Amended\%202015_Revised\%20Prefatory\%20Note\%20and\%20Comments.pdf.

${ }^{15}$ Also in the following dependent territories: Guam, Puerto Rico and U.S. Virgin Islands, see: Declaration on 7 September 2016, September 23, 2017 https://www.hcch. net/en/instruments/conventions/status-table/notifications/?csid=1016\&disp=resdn. 
applicable in relation to matters dealt with in the Convention, a possibility to chose one of the following options: the Convention will extend to all its territorial units or only to one or more of them. The United States chosen the first option. However; in accordance with Article 47 of the Convention states that there is no need to apply the convention to situations concerning only these states.

Furthermore, provisions on the administrative cooperation (Chapter II) and on inserting application through central administration (Chapter III) do not apply to maintenance between (former) spouses in PolishAmerican relations. EU made a declaration extending the scope of such provisions on the maintenance obligation between (former) spouses (Article 2.3 of the Convention), which applies also to Poland; however the United States did not made the same declaration. A declaration gives rise to obligations between the contracting states only in so far as their declarations cover the same maintenance obligations and parts of the Convention.

\title{
3. CHANGES IN RECOVERY THE CHILD SUPPORT AND OTHER FORMS OF FAMILY MAINTENANCE IN POLISH-AMERICAN RELATIONS
}

\author{
JURISDICTION IN MAINTENANCE MATTERS
}

The jurisdiction in maintenance matters is not defined in the Convention, Part IV of Polish Civil Procedure $\operatorname{Code}^{16}$ (hereinafter referred to as: "CPC") and Article 2 (Jurisdiction) of the UIFSA apply in this respect.

In accordance with Articles 1103 and 1103[3] Polish courts have jurisdiction over cases where the debtor or the creditor is so domiciled or has the habitual residence is situated in Poland. Furthermore; a Polish court has a derivative jurisdiction where the maintenance matter is recognised in connection with a proceeding concerning the matrimonial matter or determining the origin of a child only if the claims for maintenance are

${ }^{16}$ Law of 17 November 1964, Civil Procedural Code, Polish Journal of Laws 2016, item 1822 . 
examined together with the determination of the origin ${ }^{17}$. In the light of Article 1103[1] CPC one of the following connecting factors is decisive: the last place of residence or the last habitual residence in Poland of both of the spouses (provided that one of them resides or stays in Poland), the domicile or habitual residence of the creditor in Poland for a minimum period of one year prior to the launch of the proceeding (this period is reduced to 6 months if the creditor if Polish citizen) or both spouses have Polish nationality. Serving a notice or a summon on a debtor informing of the proceeding is critical in particular states in the United States, especially if this applies to the proceeding in the state or country other than the state of the residence of the debtor (is not the so-called resident) ${ }^{18}$. UIFSA introduces the principle of interstate (international) exclusive and continuous jurisdiction based on the debtor's domicile. The situation looks different in the continental law where the basis connecting factor determining the competence of court and laws is the connecting factor of domiciled or habitually residence of the maintenance creditor. Such solution shall protect the interests of the entitled person, especially a child. The domiciled or habitually residence, determining the applicable law, should be taken into account to determine the existence of the maintenance obligation and its amount with respect to factual and legal conditions of the social environment of the state in which the maintenance creditor resides and where is his centre of interests ${ }^{19}$. Residence in the particular state by the maintenance creditor or the child shall not be considered sufficient reason to adopt the jurisdiction of the authorities of this state over the maintenance debtor ${ }^{20}$.

${ }^{17}$ T. Ereciński, In: Kodeks postępowania cywilnego. Komentarz. Tom VI. Międzynarodowe postępowanie cywilne. Sąd polubowny (arbitrażowy) [Civil Procedural Code. Commentary, Vol. VI. International Civil Proceedings. Court of Arbitration], ed.T. Ereciński, Warszawa: Wolters Kluwer, 2017, 96-99.

${ }^{18}$ Article 2, section 201 UIFSA, September 20, 2017, http://www.uniformlaws.org/ shared/docs/interstate\%20family\%20support/UIFSA_2008_Final_Amended\%202015_ Revised\%20Prefatory\%20Note\%20and\%20Comments.pdf.

${ }^{19}$ A. Bonomi, Explanatory Report on the Hague Protocol of 23 November 2007 on the Law Applicable to Maintenance Obligations, Hague: HCCH Publications, 2013, 20.

${ }^{20}$ Kulko v. Superior Court, 436 U.S.84 (1978). 
An amendment to UIFSA dated 1996 extended the catalogue to the domiciled residence of the child, similar to the provisions of the continental law. Furthermore, according to UIFSA, the court of other state (State) will be the competent court if the debtor accepts its jurisdiction.

A place of cohabitation of the debtor and creditor can be considered as a ground of jurisdiction, as well as the fact of conception of the child in the particular state (prima facie evidence that the child comes from the debtor or the presumption of origin arising from the paternity's registers, which are kept in some states, is sufficient $\left.t^{21}\right)^{22}$. The court's jurisdiction can be also justified by the fact that the maintenance debtor plans to leave the territory of particular state in order to avoid personal liability. In the event of maintenance between (former) spouses their last common place of cohabitation has a substantial impact on determining the jurisdiction. The last place of cohabitation is understood as residence on the territory of one state (State). UIFSA resolved also numerous in practice positive jurisdiction disputes leading to situations that in one and the same case between the same parties have been given different decisions in different states.

\section{RECOGNITION AND ENFORCEMENT OF FOREIGN JUDGMENTS}

Pursuant to Article 19.1 of the Convention recognized and enforced is a decision rendered by a judicial or administrative authority in respect of a maintenance obligation, as well as a settlement or agreement concluded before or approved by such an authority. If a decision does not relate solely to a maintenance obligation, the effect of Article 19 is limited to the parts of the decision which concern maintenance obligations.

Starting from 1 January 2017 the Convention applies to each case in Polish-American relations when the central authority receives a request, as well as when the competent authority of the requested State receives a direct request for recognition or enforcement of the judgment (Article 56). The date of the receipt of a request may or may not be the same as

${ }^{21}$ Article 2 section 201 UIFSA, URESA130.201, www.leg.state.nv.us/nrs/NRS-130. html\#NRS130Sec6115.

${ }^{22}$ URESA130.025, www.leg.state.nv.us/nrs/NRS-130.html\#NRS130Sec6115. 
the date of the submission of the request. In respect of maintenance obligations arising from a parent-child relationship towards a person under the age of 21 years, the Convention applies also to enforcement of maintenance judgment or maintenance agreement in relation to payments due before the Convention entered into force between Poland and the United States (which is prior January 1, 2017).

The Convention does not introduce the principle of autonomy in recognition and enforcement of maintenance judgments. The entry of the Convention into force, does not mean that the United States agreed to waive the registration's duty of the Polish decisions awarding maintenance, and Polish authorities - a declaration of enforceability of the American judgment. Polish and American provisions have been unified in the area of recognition and enforcement of maintenance decisions. In the light of Article 23 of the Convention the recognition and enforcement procedures are subjected to the laws of the requested State, which means Articles 1145-1152 CPC and Article 6 of the UIFSA, however only to the extent not regulated in the Convention.

The provisions of the Convention are inspired on proceedings for a declaration of enforceability of a foreign decision in Regulation (EC) No 4/2009 of 18 December 2008 on jurisdiction, applicable law, recognition and enforcement of decisions and cooperation in matters relating to maintenance obligation $\mathrm{s}^{23}$. An obligation to declare enforceable in a separate proceedings applies only to Denmark and Great Britain, the States not bound by the Hague Protocol of 23 November 2007 on the law applicable to maintenance obligations ${ }^{24}$. A decision given in a Member State being a party to the Hague Protocol 2007 and enforced in that State, are also enforceable in another Member State without the need for a declaration of enforceability (Article 17.1 of the Regulation (EC) No 4/2009) and under the same conditions as a national decision (Article 41.1 of the Regulation (EC) No 4/2009).

The acceleration and informal procedure of recognition and enforcement of maintenance judgment is considered as an improvement. If an application for recognition and enforcement of a decision has been made

\footnotetext{
${ }^{23}$ Articles 26-38, EU Journal of Laws L 2009, No 7, p. 1.

${ }^{24}$ EU Journal of Laws L of 16 December 2009, No 331, p. 19.
} 
through Central Authorities, the requested Central Authority should promptly refer the application to the competent authority and such competent authority should without delay declare the decision enforceable or register the decision for enforcement (Article 23.2 of the Convention). "Without delay" means as soon as possible. Similarly, the competent authority which received the request directly should without delay declare the decision enforceable or register the decision for enforcement (Article 23.3 of the Convention). The principle that both parties should be heard is precluded at this stage of the proceeding, neither of the party is entitle to make any submissions on the application. An enforcement or registration may be refused only if recognition and enforcement of the decision is manifestly incompatible with the public policy of the requested State (Article 23.4 of the Convention). Next, the applicant and the respondent shall be promptly notified of the declaration or registration or the refusal of such declaration or registration (Article 23.5 of the Convention). Only thereafter the parties may lodge a challenge or an appeal within 30 days of notification of the declaration or registration or the refusal of such declaration or registration. If the contesting party is not resident in the State in which the declaration or registration was made or refused, the challenge or appeal shall be lodged within 60 days of notification.

A challenge or an appeal may be only founded on grounds for non-recognition or non-execution specified in Article 22 of the Convention, or on grounds for recognition and enforcement as defined in Article 20 of the Convention and on the authenticity or integrity of any document required by the Convention for recognition and enforcement.

The applicant and the respondent shall be promptly notified of the decision following the challenge or the appeal (Article 23.9 of the Convention). The law of the requested State decides whether an appeal will cause the suspension of the enforcement of the decision, however a further appeal, if permitted by the law of the requested State, will not have the effect of staying the enforcement of the decision unless there are exceptional circumstances (Article 23.10 of the Convention).

It should be stressed that the competent authority is required to act immediately in taking any decision on recognition and enforcement, including any appeal (Article 23.10 of the Convention). The Convention allows the parties to choose an alternative adversarial procedure at any of 
its stage (Article 24 of the Convention). So far, neither Poland nor the United States did not use such opportunity. Prior to the entry into force of the Convention, the maintenance decisions of the United States courts were subject to automatic recognition pursuant to Article 1145 CPC, without any special procedure being required ${ }^{25}$. Such decisions were effective at the same time, in which they started to have effect in the State of origin, provided that certain pre-conditions were met (Article 1146 CPC). Anyone, who had a legitimate interest may apply to the Regional Court for a decision to recognize or not the foreign court's decision. Nevertheless; the recognition of the decision was each time considered by polish national authority as a preliminary question and was not legally binding for other authorities.

On the other hand, the enforcement of the maintenance decision of the United States court requires the prior declaration of the Polish court concerning enforceability of such decision (Article 1150 CPC). Contrary to the Convention, CPC state that the proceeding will be adversarial. The debtor may exercise his right and presents his position within 2 weeks following the receipt of a copy of a motion (Article 1151[1] CPC). A declaration of enforceability is dependent on the enforcement of the decision in the State of origin and an absence of obstacles to refuse recognition of such decision (Article 1146 para. 1-2 CPC). The court's decision on an agreement enforceable may be appealed from to the Appeal Court within one week time frame from notification of such decision (Article 394 para. 2 CPC). The decision of the Appeal Court may be subject to appeal before the Supreme Court within 2 months time frame (Article 398[5] \$2 CPC). It is possible to make a request to re-open the proceeding only if such request is permitted (Articles 1151[1] para. 3 in conjunction with 399-416(1) CPC).

Each maintenance/support order issued in another state or in a foreign State has to be registered in the United States (Article 6 UIFSA), even after the Convention entered into force. In practice, the UIFSA provisions concerning the relation between particular states, applied to international cases. The change to UIFSA from 2001 allowed to apply the UIFSA provision to

${ }^{25}$ Since 1 July 2009 (the entry into force of the Law on the amendment of Civil Procedure Code and some other acts of 5 December 2008; Polish Journal of Laws 2008, No 234, item 1571). 
the maintenance decisions issued outside the United States. This was possible due to the extension of the definition of "State" to the foreign States.

The state court shall immediately inform the maintenance debtor on the consequences of the registration of such maintenance order. From the moment when the maintenance debtor receive a notification the foreign decision has a status equal to the decision rendered by the state court. In such situation, the maintenance debtor obtains the right of defense. The maintenance debtor may object to the registration of the foreign decision within 20 days (before the entry into force of the 2007 Convention in Polish-American relations) of the date of the registration of such decision, even if the maintenance debtor has his place of residence in other state (State). UIFSA provides for shorter time frame for objection than the Convention. In practice, however was and are used the longer time frames defined in the state laws ${ }^{26}$. An absence of objection causes that the foreign decision is declared immediately enforceable and such decision is transferred to the relevant state agency for enforcement $\mathrm{t}^{27}$.

Orders for the deduction of maintenance from remuneration for work issued in another state $e^{28}$ (Article 5 section 501-503 UIFSA) are enforced by virtues of law, without the need to register. Also administrative enforcement of orders, by the support enforcement agency of the particular state to be giving aid to enforce child support, does not need to be registered. However, any change to the decision given in another states (State) has to be registered.

Article 25 of the Convention precisely defines what documents should accompany an application for recognition and enforcement maintenance decisions issued by Polish courts in the United States. This is the only situation when the Convention specifies the list of required documents. In the event of other applications each State is been given a possibility to determine the list of required documents.

Recognition and enforcement of the decision depend on whether the competent authority of the State, which issued the decision, having a juris-

${ }^{26}$ This term is considered by UIFSA as "suggested", por. Comment to Article 6, section 605 UIFSA, p. 81.

${ }^{27}$ J.M. Łukasiewicz, M. Aksamitowska-Kobos, op. cit., 651.

${ }^{28}$ The 1996 reform of UIFSA imposed on employers a number of duties on deduction from remuneration amounts of maintenance awarded in another state. 
diction based on one of the grounds specified alternatively in Article 20.1 of the Convention (the so-called derivative jurisdiction). One of the reasons listed in Article 20.1 is sufficient, e.g. the respondent was habitually resident in the State of origin at the time proceedings were instituted; the respondent has submitted to the jurisdiction either expressly or by defending on the merits of the case without objecting to the jurisdiction at the first available opportunity; or the child for whom maintenance was ordered was habitually resident in the State of origin at the time proceedings were instituted, provided that the respondent has lived with the child in that State or has resided in that State and provided support for the child there.

The United States did not accept the ground of jurisdiction based on the circumstances related with a person entitled to maintenance and in accordance with Articles 20 and 62 of the 207 Convention made a reservation $^{29}$ that it will not recognize or enforce maintenance decisions issued by:

1) the competent authority of the creditor habitual resident at the time proceedings were instituted;

2) the authority exercising jurisdiction on a matter of personal status or parental responsibility,

3) the authority chosen by the parties by means of a written agreement to the jurisdiction.

This means that in cases where the jurisdiction of Polish courts result from the habitual residence of the creditor (e.g. the child), the agreement to the jurisdiction or the derivative jurisdiction, the decision of Polish court is recognized and enforced only if the United States authorities would in similar factual circumstances confer or would have conferred jurisdiction to make such a decision (Article 20.3 the Convention). If recognition of a decision issued by Polish court is not possible as a result of a reservation made by the United States and because the debtor has his habitual residence in the United States, the United States takes all appropriate measures to establish a decision for the benefit of the creditor (Article 20.4 the Convention). If a decision of Polish court in favour of a child under the age of 18 years cannot be recognized due to the reservation made by the United States, such decision will be accepted as establishing the eligibility

${ }^{29}$ Declaration of 7 September 2016, September 23, 2017 https://www.hcch.net/en/ instruments/conventions/status-table/notifications/?csid=1016\& disp=resdn. 
of that child for maintenance in the United States (Aticle 20.5 the Convention). Polish law also states, that the recognition or enforcement of decisions issued by foreign courts cannot be implemented if the decision was made in the matter belonging to the exclusive jurisdiction of the Polish courts (Article 1146 para. 1 point $2 \mathrm{CPC}$ ). Because the maintenance matters have never be considered as belonging to the exclusive jurisdiction of Polish courts, they constitute the obligatory grounds for refusal.

The Convention do not introduce material changes in Polish-American relations to the extent of other grounds of refusal of recognition and enforcement of the foreign decision. It is worth noting the optional character of such grounds, this means that the authority assessing the application of recognition and enforcement of the foreign decisions does not have to take them into account.

Grounds for refusing recognition and enforcement listed in Article 22 of the Convention were known in both Polish laws (Article 1146 and $1150 \mathrm{CPC}$ ) and American laws (Article 2 UIFSA) prior the entry of the Convention into force. The following reasons are considered as grounds for refusing recognition an enforcement: proceeding is pending before an authority of the requested State; the decision is incompatible with a decision rendered between the same parties and having the same purpose, either in the requested State or in another State, provided that this latter decision fulfils the conditions necessary for its recognition and enforcement in the requested State; the respondent did not receive a proper notice of the proceedings and did not have an opportunity to protect his rights (e.g. appeal). The public order clause is also considered as a ground for refusing recognition and enforcement of a decision. Such clause is known in the state laws, although it has not been regulated at Federal level. The public order clause has been introduced to UIFSA only after the implementation of the Convention and applies only to applications submitted on the basis of the Convention.

Such solution resulted from the general principle of UIFSA according to which an objection is necessary to refuse the registration ${ }^{30}$ and the pub-

${ }^{30}$ According to state laws (i.e. New York), contradiction to the fundamental principles of laws constitutes the grounds for non-recognition of a foreign decision, J.M. Eukasiewicz, M. Aksamitowska-Kobos, op. cit., 650. 
lic order clause is taken into account ex officio. The foreign decision can be recognised only when such decision has effect in the State of origin and can be enforced only if it is enforceable in the State of origin (Article 20.6 of the Convention, Articles 1146 para 1 point 1 and 1150 CPV, Article 6 section 607 point 4 (a) UIFSA).

Next conventional ground for refusing: obtaining a decision as an outcome of a fraud was considered as a ground for refusing recognition and enforcement of a foreign decisions also prior the entry of the Convention into force. Fraud in Polish law is considered as a circumstance constituting the grounds for reopening the proceedings to determine whether the decision of the foreign court is eligible for recognition and declare the enforceability (Articles 1148[1] para. 3, 1121[1] para. 3 in conjunctions with Article 403 para. 3 CPC).

Issue a decision in breach of Article 18 of the Convention is a new, previously unknown reason for refusing recognition and enforcement of a decision in Polis-American relations. The debtor cannot bring a proceedings to modify or to make a new decision in the State other than the State of the habitual residence of the creditor, where a decision was made, as long as the creditor remains his habitual residence in this State. Such construction should protect the creditor, who has already obtain a decision, against proceeding to modify or to make a new decision in the State where the creditor does not have his habitual residence. The court of the State, where the creditor does not have his habitual residence, should dismiss ex officio the request of the debtor to modify or to make a new decision.

From the United States point of view, it is particular important that the authority of the requested State cannot neither introduce any changes to the finding of fact on which the authority of the State of origin based its jurisdiction (Article 27 of the Convention) nor cannot review the merits of a foreign decision (Article 28 of the Convention). Such restrictions haven't resulted for a long time neither from Federal nor state laws. The absent of such regulations caused the refusal of registration or issuing new decisions instead of recognition of the foreign decision and consequently, the existence of few, often contradictory decisions rendered between the same parties. These problems were solved due to the UIFSA regulations of 1992 .

In the light of Article 47 of the Convention, the competent authority of a particular state is not bound to recognise or enforce a decision 
from another foreign State solely because the decision has been recognised or enforced in another US state under this Convention, even though the competent authority is entitled to recognise and enforce the foreign decision. Such decision has to be recognised and enforced separately in each state. The foreign decision is not automatically recognised or enforced in any other state only because it was recognised and enforced by the competent authorities in another state.

In accordance with Article 37 of the Convention the provisions of UIFSA still apply to direct applications to release or modify a decision of Polish court in the United States(Article 1-6). Per analogy, applications from the United States are recognized pursuant to provisions of the CPC.

All proceedings with a foreign element are ruled since years according the same rule which states that the enforcement shall take place in accordance with the law of the State where the proceedings takes place. The same rule, with certain reservations aiming at unification of the enforcement in the Convention States, was also expressed in Article 32 of the Convention. First, the Convention States are obliged to immediate performance of the decisions. Second, in the case of applications through Central Authorities, after a decision has been declared enforceable or registered for enforcement, the applicant shall not be required to take any further action prior the enforcement of the decision. Furthermore; the duration of the maintenance obligation should be estimated according to the rules applicable in the State of origin of the decision. On the other hand, any limitation on the period for which arrears may be enforced shall be determined either by the law of the State of origin of the decision or by the law of the State addressed, whichever provides for the longer limitation period. The State, in which the decision is enforced, is obliged to provide at least the same range of enforcement methods for cases under the Convention as are available in domestic cases (Article 33 of the Convention). The Convention imposes on each State an obligation to make available in internal law effective measures to enforce decisions under this Convention (Article 34). Similar regulation concerning the enforcement of the decision were included in the Regulation (EC) No 4/2009.

The term "creditor" has been extended and is considered as a novelty in Polish-American relations. The term 'creditor' includes also a public body acting in place of an individual to whom maintenance is owed or one 
to which reimbursement is owed for benefits provided in place of maintenance (Article 3 in conjunction with Article 36.1 of the Convention). A public body may seek recognition or claim enforcement of a decision rendered against a debtor on the application of a public body which claims payment of benefits provided in place of maintenance; as well as a decision rendered between a creditor and debtor to the extent of the benefits provided to the creditor in place of maintenance (Article 36.3 of the Convention). The right of a public body to act in place of an individual to whom maintenance is owed or to seek reimbursement of benefits provided to the creditor in place of maintenance shall be governed by the law to which the body is subject (Article 36.2of the Convention). Analogous provisions were agreed in the Regulation (EC) No 4/2009.

\section{APPLICATIONS AND REQUIRED DOCUMENTS}

So far in the United States applied 9 questionnaires ${ }^{31}$ :

1) Confirmation / forwarding and acknowledgement of receipt

2) Harmonised application form for maintenance

3) General statement

4) Statement on establishment of paternity

5) Statement on direct maintenance payments and custody rights

6) Application for search for a person and/or property

7) Application for enforcement of a decision

8) Declaration of enforceability of the decision in Poland

9) Information on the decision and statement on arrears.

These forms were bilingual, which allowed to avoid certified translations. The Polish literature have described in details what form and required documents should be attached to the application for maintenance in the United States, the enforcement of the Polish decision awarding maintenance and the modification of the decision given in the United States ${ }^{32}$.

${ }^{31}$ Bilingual form applications: www.acf.hhs.gov/programs/cse/pol/IM/2007/im-0702a.doc/, A Caseworker's Guide to Processing Cases with Poland, more in M. Aksamitowska-Kobos, J.M. Łukasiewicz, op. cit.

${ }^{32}$ M. Aksamitowska-Kobos, J.M. Łukasiewicz, op.cit., 648-649. 
The Convention is accompanied by two standard forms utilized by the Central Authorities: the transmission of the application to the Central Authority of the requested State (Annex I, Article 12.2) and the acceptance of the application by the authority (Annex II, Article 12.3). The HCCH prepared also the forms for the application the preliminary ruling, modification, recognition and enforcement of a decision. Both, Poland ${ }^{33}$ and the United States ${ }^{34}$, expressed their willingness to utilize such forms, particularly as regards application for recognition and enforcement of a decision. It is worth noting that such forms are modeled on application forms utilized by the EU Member States under the Regulation (EU) No 4/2009 ${ }^{35}$. It is important in terms to a uniform implementation of recovery of family maintenance on a global scale.

According to Article 44 of the Convention applications and related documents shall be in the original language, and shall be accompanied by a translation into an official language of the requested State. In the case of the applications through Central Authorities, the Authority of the Stare in which the applicant resides, will incur the costs of the translation. Each Central Authority is obliged to cover the charge on an application for the provision of their services under the Convention (Article 8). If the application is made without the intervention of the Central Authority, all the costs will be covered by the applicant. Notwithstanding Article 8, the requesting Central Authority may charge the applicant for the costs of translation of an application and related documents, except in so far as those costs may be covered by its system of legal assistance.

Article 11 of the Convention lists only essential elements of an application making through the Central Authorities, while leaving each State the possibility of clarifying any further documents by declaration (Articles 11.1 (g) in conjunction with 63). The Convention states that the application shall be accompanied by any necessary supporting information

${ }^{33}$ Poland, Country profile-2007 Child Support Convention, p. 16, October 23, 2017, http://hcch.cloudapp.net/smartlets/sfjsp?interviewID=hcchcp2012.

${ }^{34}$ United States, Country profile-2007 Child Support Convention, p. 18, October 23, 2017, http://hcch.cloudapp.net/smartlets/sfjsp?interviewID=hcchcp2012.

${ }^{35}$ Practical Handbook for Caseworkers under the 2007 Hague Child Support Convention, The Hague: HCCH Publications, 2013, 257-277, October 23, 2017 https:// www.hcch.net/en/publications-and-studies/details4/?pid=6095. 
or documentation ${ }^{36}$ (Article 11.3), while leaving each State the right to decide which concrete documentation is required to each type of application. There is an exception to this general rule, included in Article 10 of the Convention. The Convention determines the complete list of documents which should be attached to the application submitted by creditor to recognize or enforce a decision (Article 10.1 (a)) or to the application of the debtor to recognize a decision or an equivalent procedure leading to the suspension, or limiting the enforcement, of a previous decision in the requested State (Article 10.2 (a)), although the States could make some reservations in this scope (Article 25.3 of the Convention). The Central Authority in Poland, For example, is not allowed to accept a summary or an extract of a decision given by the competent authority of the requested State, contrary to the authority in the United States ${ }^{37}$.

Poland made a declaration on the content of applications submit through the Central Authorities and documents required for to submit such applications is a part of the Annex III to the Decision on the approval, on behalf of the European Union, of the Convention. Annex III precisely clarifies what documents are required to each type of the application. Through such a solution, the applicant receives a clear and precise information.

The United States did not make a declaration clarifying what documents exactly should be attached to the particular type of the applica$\operatorname{tion}^{38}$. There is a risk that the authorities of different states will demand different documents. Such declaration can be made at any time and it is

${ }^{36}$ Similarly, the New York Convention 1956 on the recovery aboard of maintenance, Polish Journal of Laws 1961, No 17, items 87 and 88, and problems encountered due to this regulation, see. J.M. Łukasiewicz, M. Aksamitowska-Kobos, „Egzekucja alimentów na rzecz dziecka od zobowiązanego przebywającego na terenie Anglii oraz Walii na podstawie rozporządzenia Rady (WE) z 18.12.2008 r. - 4/2009 - cz. II" [Enforcement of maintenance for child from a England and Welsh resident based on the Regulation (EU) No 4/2009, part II], Monitor Prawniczy (19)2015: 1026.

37 Poland, Country profile - 2007 Child Support Convention, p. 15; United States, Country profile - 2007 Child Support Convention, p. 17, November 23, 2017, http:// hcch.cloudapp.net/smartlets/sfjsp?interviewID=hcchcp2012.

${ }^{38}$ United States, Country profile-2007 Child Support Convention, p. 24. 
not excluded that in the future the United States will sign such declaration what would be highly desired (Article 63.1 of the Convention).

Contrary to the Central Authority in the United States ${ }^{39}$, the Central Authorities in Poland do not have a opportunity to submit applications or documents electronically ${ }^{40}$.

\section{COOPERATION BETWEEN POLISH AND AMERICAN CENTRAL AUTHORITIES}

The most important change made by the Convention is the introduction of a uniform system of cooperation between the States in recovery of the maintenance on the global scale. The uniform system appointed in each State the Central Authorities having equal competences, operating on the same rules through uniform procedure. Since long exists in the United States the network of federal and state authorities supporting financially children and helping to recover the outstanding child support and other family maintenance from the debtors who do not fulfill their obligations. The effective system of cooperation in recovery of the child support and other family maintenance was not developed so far in Polish-American relations. The United States, contrary to Poland, did not sign the New York Convention of 1956 on the recovery aboard of maintenance ${ }^{41}$. This means that the United States does not have an experience in cooperation between States in recovery of maintenance on the basis of the requested Central Authorities in particular States.

According to the Convention, the United States Department of Health and Human Services, Office of Child Support Enforcement (OCSE) ${ }^{42}$ is designated as a Central Authority in the United States. The OCSE does

${ }^{39}$ Ibidem, p. 18.

${ }^{40}$ Poland, Country profile - 2007 Child Support Convention, p. 16.

${ }^{41}$ Polish Journal of Laws 1961, No 17, items 87 and 88.

42330 C Street SW, Washington, DC 20201, September 9, 2017 https://www.hcch. net/en/states/authorities/details3/?aid $=1076$, is the government agency of the United States department for health and social welfare, created in 1975 . The agency supports the state agencies and coordinates enforcement of maintenance for children from parents who reside in different states of the United States or States. 
not examine the applications submitted under the Convention. Such application should be sent directly to child support agency or support enforcement agency operating in this state, in which the debtor is staying $^{43}$ (Article 7 section 204 UIFSA).

Pursuant to the Act on social insurance the state agencies administering the federal financial assistance program for children and due to this they fulfill tasks and functions of the Central Authority. The state agencies are responsible for the implementation of the state assistance programs for children, funded from federal assets, and for enforcement of maintenance from debtors. The tasks of support enforcement agency can be performed not only by the government offices, but also other government agencies and even the private agencies. In case of such delegation, the support enforcement agencies are controlled mainly in financial terms.

The alimony fund operating in Poland on the basis of the Act on assistance for people entitled to alimonies is an equivalent of such program ${ }^{44}$. Executive bodies of the commune (the head of the commute, the mayor, the president of a city) are responsible for implementation of the objectives of this act. However, in practice such objectives are completed by City Social Assistance Centers (MOPS).

The Central Authority in Poland is Department of International Cooperation and Human Rights within the Ministry of Justice; however its objectives in this area are implemented by regional courts. Based on the Communicate of 18 November 1987 the Minister of Justice mandated the presidents of the regional courts to receipt of the applications for recovery of the child support and other family maintenance from persons having habitual residence in the United States.

In accordance with Article 5 the Central Authorities not only cooperate with each other but also seek as far as possible solutions to difficulties which arise in the application of the Convention. The applicant may, through the Central Authorities, submit an application for issuance of a decision or for modification of an existing decision, or for recognition

${ }^{43}$ The list of agencies is available on the OCSE websie: https://www.acf.hhs.gov/css/ ikowaniu rg-state-map.

${ }^{44}$ Act of 7 September 2007 upon Assistance to the Persons Entitled to Alimony (hereinafter referred to as: u.p.o.u.a.; Polish Journal of Laws 2017, item 489). 
and enforcement of a decision in other state (Article 6). Authorities are obliged to grant the applicant all assistance required with these applications, along with their power to start the proceedings in respect of such applications. The Authorities are entitled to provide legal assistance, to help locate the debtor or the creditor, to help obtain relevant information concerning the income of the debtor or creditor, to encourage amicable solutions, to facilitate the collection and expeditious transfer of maintenance payments, to provide assistance in establishing parentage, or to facilitate the obtaining of documentary. The person, who has his/her habitual residence in this State, is entitled to the assistance of the Central Authority of that State (Article 9). The Central Authority of the requesting State is responsible for the correctness of the application and for the completeness of the attached documents (Article 12.1). Further, the requested Central Authority shall, within 6 weeks from the date of receipt of the application, acknowledge receipt in the form set out in Annex 2. The provisions of the Convention impose on the requested Central Authority an obligation to inform the requesting authority. Within 6 weeks the requested authority will inform on initial steps have been or will be taken to deal with the application and within the next 3 months after the acknowledgement on the status of the application (Articles 12.3 and 12.4). Furthermore; the requesting and requested Central Authorities are obliged to keep each other informed of the person or unit responsible for a particular case and the progress of the case (Article 12.5). They should also provide timely responses to their enquiries. In practice, this is essential to handle the case within reasonable time. Additionally, in the light of Articles 12.6 and 12.7 the Central Authorities should process a case as quickly as possible and employ the most rapid and efficient means of communication. These regulation are the response to the current communication and cooperation problems occurring between the competent authorities being responsible for enforcement of maintenance in cross-border cases. Also States bound by the New York Convention of 1956 faced the same problems caused by lack of any regulations in this area.

Regulation (EU) No 4/2009 contains similar provisions regard with the processing the applications and cases through Central Authorities. The only difference is that the time frames are shorter that in Convention and 
are 30 days to sent a confirmation of the receipt of the application and 60 - to inform of the status of the application (Article 58.3 and 58.4).

The provisions of the Convention concerning the tasks and cooperation between the central authorities are regarded as milestones for improving the recovery of maintenance in Polish-American relations ${ }^{45}$.

\section{LEGAL ASSISTANCE AND COSTS}

The American doctrine highlights that the most important argument for implementation of the Convention are the provisions of this document concerning legal assistance and costs ${ }^{46}$.

Each requested State, which is responsible to consider an application, is obliged to provide the applicant free legal assistance, including effective access to procedures arising from such applications (Articles 14.1 and 14.2). Procedures for access to free legal assistance should not be more stringent than those available in equivalent domestic cases (Article 14.4). The requested State is exempt from this obligation to provide such free legal assistance if the procedures of that State enable the applicant to make the case without the need for such assistance, and the Central Authority provides such services as are necessary free of charge (Article 14.3).

However, each requested State is obliged to provide free legal assistance in respect of all applications concerning maintenance obligations arising from a parent-child relationship towards a child who under Article 15.1 is considered as a person under the age of 21 years, regardless of the applicant's financial status and the substance of the matter.

In the case of all applications other than those mentioned above, the assignment of legal assistance is subject to national law, with reservation that a person who in the State of origin has benefited from free legal assistance,

${ }^{45}$ J.M. Łukasiewicz, M. Aksamitowska-Kobos, „Egzekucja alimentów na rzecz dziecka od zobowiązanego przebywającego na terenie USA na przykładzie stanu Illinois oraz New York" [Enforcement of child support payments from a US resident on the example of Illinois and New York], Monitor Prawniczy (12) 2016: 653.

${ }^{46}$ E.M. Fish, op.cit., 42. 
is entitled, in any proceedings for recognition or enforcement, to benefit, at least to the same extent, from free legal assistance as provided for by the law of the State addressed under the same circumstances (Article 17 (b)).

The Central Authorities bear its own costs in applying this Convention and may not impose any charge on an applicant for the provision of their services under the Convention save for exceptional costs arising from a request for a specific measure (e.g. to locate the debtor, to obtain information concerning the income of the creditor and debtor or to facilitate the obtaining of documentary or other evidence) under one condition that the applicant gave his/her prior consent to the provision of those services at such cost.

\section{SUMARY}

In order to improve cooperation between States, each State bound by the Convention is obliged to submit to the Permanent Bureau of the $\mathrm{HCCH}$ information on the applicable regulations and procedures concerning maintenance, enforcement procedures (including any limitations on enforcement, in particular debtor protection rules and limitation periods), steps taken to perform specific functions imposed on the Central Authorities (Article 6), as well as to provide the applicant an effective access to the procedures (including enforcement and appeal procedures) arising from applications submitted under the Convention (Article 14).

In fulfilling their obligation to provide requested information, the States may utilize a Country Profile form, which is publicly available on the $\mathrm{HCCH}$ website. The Country Profile forms are legible and provide complete, reliable and up-to-date information, because the States are obliged to update such information. $\mathrm{HCCH}$ was able to gather in one place all information relevant to the Central Authorities and creditors.

Furthermore; $\mathrm{HCCH}$ produced a practical guide for persons responsible for handling cases under the Convention. The practical guide was translated, thanks to the European Commission, into all official EU languages ${ }^{47}$.

${ }^{47}$ November 24, 2017 https:/www.hcch.net/en/publications-and-studies/details4/? pid $=6095$. 
Initiatives and means of conveyance, taken in connection with the Convention, cannot be compared with anything else in the current activities of the $\mathrm{HCCH}$.

The Convention is a hope for maintenance creditors for more effective and faster enforcement of maintenance in the United States" 48 , and the similarity to the provisions of the Regulation (EU) No 4/2009 gives a chance for unified global cooperation between States in recovery of maintenance, as well as constitutes facilitation for central authorities examining applications EU and non-EU States based on similar principles.

\section{REFERENCES}

Aksamitowska-Kobos M. 2015. „Egzekucja alimentów na rzecz dziecka od zobowiązanego przebywającego na terenie Anglii oraz Walii na podstawie rozporządzenia Rady (WE) z 18.12.2008 r. - 4/2009 - cz. II", "Monitor Prawniczy" 19.

Bonomi A. 2013. Explanatory Report on the Hague Protocol of 23 November 2007 on the Law Applicable to Maintenance Obligations, Hague: $\mathrm{HCCH}$ Publications.

Fish E.M. 2011. "The Uniform Interstate Family Support Act (UIFSA) 2008: Enforcing International Obligations Through Cooperative Federalizm", "Journal of the American Academy of Matrimonial Lawyers" 24, October 23, 2017 http://aaml.org/sites/default/files/MAT105_3.pdf.

Ignaczewski J., Karcz M., Maciejko W., Romańska M. 2016. Alimenty: komentarz, ed. J. Ignaczewski, Warsaw: C.H. Beck.

Łukasiewicz J.M., Aksamitowska-Kobos M. 2016. „Egzekucja alimentów na rzecz dziecka od zobowiązanego przebywającego na terenie USA na przykładzie stanu Illinois oraz New York”, „Monitor Prawniczy” 12.

Poland, Country profile - 2007 Child Support Convention; United States, Country profile - 2007 Child Support Convention, 17, October 23, 2017 http:// hcch.cloudapp.net/smartlets/sfjsp?interviewID=hcchcp2012.

Practical Handbook for Caseworkers under the 2007 Hague Child Support Convention 2013. The Hague: HCCH Publications. October 23, 2017 https:// www.hcch.net/en/publications-and-studies/details4/?pid=6095.

${ }^{48}$ M. Aksamitowska-Kobos, J.M. Łukasiewicz, op. cit., 653. 
Ereciński Tadeusz. (ed.) 2017. Kodeks postępowania cywilnego. Komentarz. Tom VI. Międzynarodowe postępowanie cywilne. Sąd polubowny (arbitrażowy), Warsaw: Wolters Kluwer. 
